\title{
Cell Cycle Phase
}

National Cancer Institute

\section{Source}

National Cancer Institute. Cell Cycle Phase. NCI Thesaurus. Code C20180.

Any one of the major conceptual divisions of the eukaryotic cell cycle, based on

characteristic cytological and biochemical events, that occur in the order G1 (Gap 1)-S

(Synthesis)-G2 (Gap 2)-M (Mitosis) and lead to cell division. 